\title{
Puff-by-Puff Analysis of Selected Mainstream Smoke Constituents in The Kentucky Reference 2R4F Cigarette*
}

\author{
by \\ K.A. Wagner ${ }^{l, 2}$, R. Higby ${ }^{l}$, and K. Stutt ${ }^{l}$ \\ ${ }^{1}$ Arista Laboratories, 1941 Reymet Road, Richmond, VA 23237, USA. \\ ${ }^{2}$ Current address: Philip Morris USA, 615 Maury Street, RD \& E, Richmond, VA 23224, USA.
}

\section{SUMMARY}

A method has been developed to perform mainstream smoke (MSS) chemical analysis on individual cigarette puffs using standard equipment typically found in a smoke chemistry laboratory. The method allows for accurate delivery profiling of smoke constituents as the cigarette is consumed. This methodology can be applied to both gasand particulate phase species.

A 20-port rotary smoking machine is used for sample generation in order to effectively generate sufficient MSS for chemical analysis. The interface between the smoking machine and the sample collection trap has been modified to incorporate a custom designed puff-by-puff tee and switching valve. With this configuration, the MSS can be diverted from the smoke collection trap until the desired puff number has been reached and at that point, the smoke can be directed to the collection trap. With this configuration, a specific puff number can be consecutively collected from each of the 20 cigarettes allowing sufficient smoke to be collected for chemical analysis.

Puff-by-puff data are reported for the Kentucky reference 2R4F cigarette for selected smoke constituents. Data are presented for nicotine-free dry particulate matter (NFDPM), carbonyls, volatile organic compounds (VOCs) and tobacco-specific nitrosamines (TSNA). Puff number versus the analyte concentration, on a per puff basis, is presented. Summed data for the puff-by-puff assay are compared with average yields for whole cigarette smoke methods. All comparison data generated with the whole cigarette methods were generated using validated methods and data points were collected from a minimum of $n=150$ samples collected over two years in our laboratory. Puff number versus the analyte concentration, on a per puff basis, is presented. The total amount of mainstream analyte delivered, on a per cigarette basis, agrees well with 2R4F historical data at the $95 \%$ confidence interval demonstrating this collection method's validity. [Beitr. Tabakforsch. Int. 21 (2005) 273-279]

\section{ZUSAMMENFASSUNG}

Es wurde eine Methode zur chemischen Analyse des Hauptstromrauchs (HSR) von Zigaretten auf Zugbasis entwickelt, die mit der Standardausrüstung, die jedem chemischen Rauchlabor zur Verfügung steht, durchgeführt werden kann. Die Methode erlaubt eine präzise Aufschlüsselung der beim Rauchen der Zigarette freigesetzten Bestandteile. Mit dieser Methode lassen sich sowohl Gasphasen- als auch Partikelphasenbestandteile bestimmen. Die Probensammlung erfolgt mit einer 20-Port Rotationsabrauchmaschine, um auf effiziente Weise ausreichend HSR für die chemische Analyse zu erhalten. Die Verbindungsstelle zwischen Rauchmaschine und Auffangsystem wurde dahingehend geändert, dass ein für diesen Zweck entwickeltes Einzeleinzugsystem und ein umschaltbares Ventil integriert wurden. Mit dieser Versuchsanordnung kann der HSR vom Auffangsystem weggelenkt werden, bis die erwünschte Zugzahl erreicht ist und der Rauch dann aufgefangen werden kann. Mit dieser Anordnung kann der Rauch eines bestimmten Zuges jeder der zwanzig Zigaretten nachfolgend gesammelt werden, so dass genügend Rauch für die chemische Analyse zur Verfügung steht. Die zugweise ermittelten Werte für bestimmte Rauchbestandteile beziehen sich auf die Kentucky Referenzzigarette $2 \mathrm{R} 4 \mathrm{~F}$. Es wurden die Werte für das nikotinfreie Trockenkondensat (NFDPM), Carbonylverbindungen, flüch- 
tige organische Verbindungen (VOCs) und tabakspezifische Nitrosamine (TSNA) bestimmt. Es werden die Ausbeuten pro Zug in Abhängigkeit von der Zugzahl präsentiert. Die zugweise aufsummierten Ausbeuten wurden mit den durchschnittlichen Ausbeuten verglichen, die bei Analysen des Gesamtrauchs erhalten wurden. Alle Vergleichsdaten für die Ausbeuten pro Zigarette wurden mit validierten Methoden ermittelt und Einzelwerte für mindestens $n=150$ Proben wurden in diesem Labor über einen Zeitraum von zwei Jahren bestimmt. Die Ausbeuten pro Zug in Abhängigkeit von der Zugzahl werden präsentiert. Die berechneten Gesamtmengen pro Zigarette sind in Übereinstimmung (95\% Konfidenzintervall) mit den in der Literatur berichteten Werten für die 2R4F Zigarette und belegen die Validität dieser Methode. [Beitr. Tabakforsch. Int. 21 (2005) 273-279]

\section{RESUME}

Une méthode a été développée pour effectuer l'analyse chimique bouffée par bouffée de la fumée du courant principal (CP) à l'aide d'un équipement standard utilisé dans des laboratoires d'analyse de la fumée. La méthode permet de doser précisément les composants de la fumée délivrés au cours du fumage. Cette méthode peut être appliquée pour le dosage des composants des phases gazeuses et particulaires de la fumée.

La collecte des échantillons a été effectuée par une machine à fumer rotative à 20 canaux pour ainsi obtenir suffisamment de CP pour l'analyse chimique. La jonction entre machine à fumer et dispositif de piégeage des échantillons a été modifiée de façon à inclure un dispositif approprié de collecte bouffée par bouffée et une valve permutable. Cette configuration permet de dériver le $\mathrm{CP}$ du dispositif de piégeage jusqu'au nombre voulu de bouffées pour à ce moment recueillir la fumée dans le piège de collecte. Cette configuration permet de recueillir consécutivement un nombre spécifique de bouffées de chacune des 20 cigarettes permettant la collecte de suffisamment de fumée pour l'analyse chimique.

Les données bouffée par bouffée de la cigarette de référence Kentucky 2R4F sont rapportées pour certains composants de la fumée, parmi ceux-ci la matière particulaire anhydre et exempte de nicotine (NFDPM), les composés carbonyles, les composés organiques volatiles (VOCs) et les nitrosamines spécifiques du tabac (TSNA). Pour chaque bouffée, le nombre de bouffées par rapport à la teneur en analytes, est présenté. L'ensemble des données de l'analyse bouffée par bouffée est comparé aux rendements moyens des analyses de la fumée totale de cigarette. Toutes les données de références obtenues par analyse de la fumée totale de cigarette ont été acquises par des méthodes validées sur la base d'au moins $n=150$ échantillons, développées dans ce laboratoire au cours de deux années. Pour chaque bouffée, le nombre de bouffées comparé à la teneur en analytes, est présenté. Le rendement total en composants du CP par cigarette est en bon accord, au niveau de confiance de $95 \%$, avec les données rapportées dans la littérature pour la cigarette $2 \mathrm{R} 4 \mathrm{~F}$, indiquant la validité de cette méthode. [Beitr. Tabakforsch. Int. 21 (2005) 273-279]

\section{INTRODUCTION}

There is a significant amount of research being performed in the tobacco industry for the purpose of developing cigarettes with reduced levels of harmful smoke constituents (1). A few methods of modifying the delivery of mainstream smoke (MSS) constituents are to: add filter tips, develop novel filter materials, alter ventilation, develop low combustion products, e.g., Eclipse, Accord, and add modifiers to the tobacco to alter the smoke chemistry (1). It is widely accepted that there are more than 2000 components in tobacco and twice as many components in tobacco smoke (2). This complex smoke mixture is distributed between particulate and gas phases. Particulate phase smoke is defined as the smoke that is trapped by a Cambridge pad and gas-phase smoke is defined as the smoke that passes through a Cambridge pad (2). Furthermore, many smoke constituents will be distributed in equilibrium between the two phases in varying ratios depending on the collection conditions (3). Cigarette smoke is a complex aerosol with particles ranging in size from $0.2-1$ $\mu \mathrm{m}$. The size of the particles is greatly determined by the age of the smoke, because smoke particles tend to condense and grow with age $(2,3)$. The physical properties of smoke may necessitate a different sampling apparatus and sampling conditions depending on the properties of the constituent to be trapped.

Most methods of smoke collection for chemical analysis involve collecting the smoke from multiple cigarettes (typically 3 to 20) on a Cambridge pad, in a solvent trap, sorbent tube, or by electrostatic precipitation and then preparing the sample for instrumental analysis (3). The smoke from multiple cigarettes must be collected for most methodologies to ensure sufficient sensitivity. Online methods employing Fourier transform infrared spectroscopy (FTIR) for the determination of constituents such as carbon dioxide, carbon monoxide, acetaldehyde, nitric oxide, hydrogen cyanide, carbonyl sulfide, and formaldehyde have also been reported $(4,5)$. Similarly, online methods utilizing gas chromatography (GC) with online injection of the whole smoke have been developed $(6,7)$. These methods are limited by the range of analytes suitable to the physical constraints of the system.

It is generally well accepted that the delivery of many MSS constituents gradually increases as the cigarette is consumed, although exceptions do exist with formaldehyde being a noteworthy example $(6,8)$. This increase in delivery is attributed to the filtration of the particulate phase smoke by the tobacco column (which is consumed in subsequent puffs), reduction of the cigarette ventilation as the wrapping paper is consumed, and also loading of the filter with filtered particulate phase smoke. In addition, the lighting conditions and type of lighting device used have been documented to alter the delivery of acetaldehyde, hydrogen cyanide and various polynuclear aromatic hydrocarbons $(4,8)$. Therefore, it is clear that to effectively reduce the levels of selected smoke constituents, the point at which the smoke constituents are formed during the consumption of the cigarette must be well understood. Puff-by-puff analysis is an effective way to study the generation of smoke constituents. Researchers have also developed models that can be used to predict the delivery of nicotine-free dry particulate matter (NFDPM), nicotine and water on a puff-by-puff basis (9). 


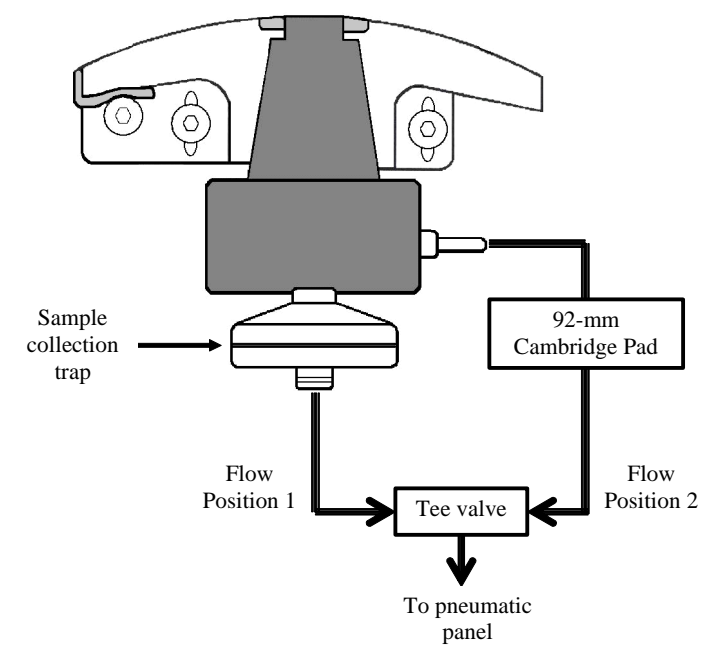

Figure 1. Puff-by-puff adapter inserted into the Borgwaldt RM 20/CSR sealing segment

FTIR is ideally suited to puff-by-puff analysis because each puff can be conveniently directed into the gas cell for analysis, but the technique does suffer limitations. Namely, FTIR is applicable to only 12 to 15 gas-phase compounds and suffers from relatively poor sensitivity (6). PARRISH and co-workers also noted that cigarette imperfections could add analytical variability because multiple puffs were not being collected from multiple cigarettes is as typically done for more traditional smoke analyses (4).

THOMAS and co-workers developed a novel gas chromatography-mass spectrometry (GC-MS) puff-by-puff method for MSS analysis (6). This method utilizes a system of valves and a smoking machine that is integrated into a GC-MS to automatically inject an aliquot of each puff taken from the cigarette. The concentrations of the smoke constituents were related to a control cigarette due to technical limitations with external calibration. Another potential limitation with using GC for puff-by-puff analysis is that the concentrations of the smoke constituents are not consistent throughout the duration of the puff (7). When the puff is drawn through the injection port sampling loop, only a very small percentage of the total puff is injected into the chromatographic system and the results may not accurately describe the average concentration per puff (7). CROOKS and co-workers developed an interesting technique for determining intrapuff nicotine yield by using a rectangular filter traveling at a constant velocity of 5 $\mathrm{cm} / \mathrm{sec}$ behind the filter butt to collect the smoke condensate during the puff. The $10-\mathrm{cm}$ filter was then cut into 5 equal segments for analysis, where each segment corresponded to 0.4 seconds of the puff (10). Although this system is able to provide intrapuff data, it is not applicable to gas-phase smoke constituents that require a liquid trap for collection.

The method presented herein was developed to perform MSS chemical analysis on individual cigarette puffs using proven methodology. This allows for accurate delivery profiling of smoke constituents as the cigarette is consumed. This methodology is valid for both gas- and partic- ulate phase species. This refined puff-by-puff method solves many of the limitations of the methods listed above. The method utilizes a 20-port rotary smoking machine coupled to a three-way valve and a specially designed puff-by-puff interface placed between the cigarette port and the smoke collection trap. With this configuration, the MSS can be diverted from the smoke collection trap until the desired puff number has been reached and at that point, the smoke can be redirected to the collection trap. Therefore, a specific puff number can be selectively collected from 20 cigarettes ensuring that sufficient smoke is collected for analysis.

\section{EXPERIMENTAL AND METHODOLOGY}

\section{Smoking machine}

Smoking was performed on a Borgwaldt Technik RM 20/CSR smoking machine (Hamburg, Germany). The cigarettes were lit using a Borgwaldt electrical resistance lighter (part number 70291220). Federal Trade Commission (FTC) cigarette conditions and smoking procedures were used for all analyses (11). A puff-by-puff, tee adapter was designed and fabricated that provided the means for performing puff-by-puff analyses. The adapter was fabricated from Ertalyte $\AA$, which is a semi-crystalline thermoplastic polyester based on polyethylene terephthalate (PET-P). A diagram of the tee adapter, which is shown inserted into the sealing segment of the Borgwaldt smoking machine, is given in Figure 1. The adapter was machined with a standard 29/34 scientific glassware taper that is used on the Cambridge pad holder supplied by the manufacturer. Therefore, the adapter is easily fitted into the sealing segment without modifying the smoking machine. Figure 1 is shown with a 44-mm Cambridge filter pad as the collection media. When gas-phase species are collected, a liquid trap either replaces the Cambridge pad holder or is placed behind the pad holder, depending on the methodology employed.

A smoking run is performed using the procedure described with the following example: If puff 2 is the puff of interest, the tee valve is placed in Flow Position 2 (Figure 1) during the lighting puff. Flow Position 2 directs the smoke to a 92-mm Cambridge filter pad which is simply placed in line in order to protect the pneumatic panel from the waste smoke condensate from the puffs that will not be collected for analysis. This filter pad is replaced after every smoke collection run and is not used for the analysis. After the first puff has been taken on the $20^{\text {th }}$ cigarette, the tee valve is switched to Flow Position 1, which directs the smoke to the primary sample collection trap that will be used for analysis. After the desired puff has been collected from all 20 cigarettes, the cigarettes are removed from the smoking machine before the next puff is taken. As per our normal whole cigarette smoke collection procedures, six clearing puffs were taken for the carbonyl collection while five clearing puffs were taken for NFDPM, volatile organic compounds (VOCs), and tobacco-specific nitrosamines (TSNA). Smoking for this study was performed in triplicate. Therefore, all data reported for $2 \mathrm{R} 4 \mathrm{~F}$ are the average of three separate results. 


\section{NFDPM, water, and nicotine}

Water and nicotine were determined by GC while NFDPM was calculated from the resulting values with methodology similar to International Standard (ISO) 4387 (12). A Hewlett-Packard 5890 GC equipped with FID and TCD detectors (Palo Alto, California) was used for the determination of water and nicotine. Nicotine $(98 \%+$ purity) was purchased from Aldrich (Milwaukee, WI).

\section{Ketones and aldehydes}

The ketones and aldehydes (collectively referred to as carbonyls) determined were formaldehyde, acetaldehyde, acrolein, acetone, propionaldehyde, crotonaldehyde, butyraldehyde, and methyl ethyl ketone. The carbonyls were determined with a Waters 2695 HPLC equipped with a 2487 UV detector (Milford, Massachusetts). A C18 reversedphase column is used to resolve the carbonyls from potential interferences. MSS was collected using two 70-mL capillary impingers (Research Glass, Richmond, VA) placed directly behind the cigarette mouthpiece. The impingers were prepared to contain a sufficient molar concentration of acidified 2,4-dinitrophenylhydrazine (DNPH) solution $(25-\mathrm{mL})$ to derivatize the carbonyls into their respective hydrazone derivatives. The DNPH moiety was detected at $355 \mathrm{~nm}$. The carbonyl-DNPH derivative standards were purchased from ChemService (West Chester, PA).

\section{Volatile organic compounds}

The VOCs determined were 1,3-butadiene, isoprene, acrylonitrile, benzene, toluene and styrene. The VOCs were determined with GC-MS. A DB-WAX column (1 m $\times 0.25 \mathrm{~mm} \times 0.25 \mu \mathrm{m}$ ) coupled to a DB-5MS column $(60 \mathrm{~m} \times 0.25 \mathrm{~mm} \times 1.0 \mu \mathrm{m})$ were used to resolve the VOCs from potential interferences. MSS was collected on a 44-mm Cambridge filter followed by one 70-mL, coursefritted impinger (Research Glass, Richmond, VA) containing $20 \mathrm{~mL}$ of methanol that was immersed in a dry-ice/isopropyl alcohol bath. After smoking, the Cambridge filter was transferred to the impinger. Benzene- $\mathrm{d}_{6}$ was added to the impinger as an internal standard and the sample was vortexed briefly. The extract was subsequently analyzed using an Agilent 6890 GC-MS equipped with a 5973 mass selective detector (Palo Alto, California). All of the standards were purchased from Acros Organics (Pittsburg, PA) with the exception of isoprene and the benzene- $\mathrm{d}_{6}$, which were purchased from Aldrich (Milwaukee, WI).

\section{Tobacco-specific nitrosamines}

The TSNA determined were $N$-nitrosonornicotine (NNN), 4( $N$-nitrosomethylamino)-1-(3-pyridyl)-1-butanone (NNK), $N$-nitrosoanatabine (NAT) and $N$-nitrosoanabasine (NAB). MSS was collected on a 44-mm Cambridge filter. Deuterated internal standards (d-NNN, and d-NNK) were added to the filter and then the TSNA were extracted from the Cambridge pad with 20-mL of 100-mmol ammonium acetate on a wrist action shaker. The extraction vessel used was a 40 $\mathrm{mL}$ amber bottle with a PTFE screw cap. A Micromass Quattro Ultima LC-MS/MS equipped with a Waters $1525 \mu$ binary HPLC system (Milford, Massachusetts) was used for the determination of the TSNA. A C18 reversed-phase column was used to resolve TSNA from potential interference. The standards were purchased from Toronto Research Chemicals (Toronto, Ontario) and the internal standards were purchased from CDN Isotopes (Pointe-Claire, Québec).

\section{RESULTS AND DISCUSSION}

Puff-by-puff data are presented in Table 1 for the Kentucky reference 2R4F cigarette. Data are presented for NFDPM, TSNA, VOCs, and carbonyls. Each data point represents the average of three separate replicates where each replicate was comprised of the smoke collected from 20 cigarettes for the specified puff number. Our laboratory uses the $2 \mathrm{R} 4 \mathrm{~F}$ cigarette as an internal laboratory method control for routine smoke analysis using our fully validated methods. The methods were validated in accordance with our ISO 17025 scope of accreditation (certificate number 1873.01) and included linearity, accuracy, intra-assay precision, intermediate precision, stability, limits of detection, and limits of quantitation. Data from the $2 \mathrm{R} 4 \mathrm{~F}$, collected over two or more years, are used by this laboratory for process control charts. Puff-by-puff method validity has been proven for both particulate- and gas-phase analyses by comparing the sum of the analyte collected on a puffby-puff basis with the historical control data. The total amount of mainstream analyte produced using the puff-bypuff method, on a per cigarette basis, agrees well with 2R4F historical data at the $95 \%$ confidence interval demonstrating this collection method's validity.

The puff-by-puff delivery data for $2 \mathrm{R} 4 \mathrm{~F}$ smoked under FTC conditions are presented graphically for NFDPM, TSNA, VOCs, and carbonyls in Figures 2 to 5. As expected, there is a trend in which the analyte delivery increases with increasing puff count. This is likely due to a decrease in filter-tip filtration as particulate phase smoke collects on the filter tip and also due to filtration of the particulate phase smoke by the tobacco column, which is subsequently consumed in later puffs. This trend in which analyte concentration increases with puff number is more linear for species that are strictly found in the particulate phase, such as NFDPM and TSNA, than for gas-phase species. It is worth noting that the first and last puffs may produce less of the analyte than expected if a linear regression is applied to the data. The delivery of the first puff being slightly below the linear trend may be explained by a decrease in the puff efficiency due to lighting and also because there is not any particulate phase smoke deposited on the tobacco column from previous puffs. The delivery of the last puff being slightly below the linear trend is easily explained by the fact that not all of the 20 cigarettes were puffed a ninth time because the Borgwaldt RM 20/CSR is capable of partial puffs and the cigarettes were smoked to FTC butt length, not puff count.

The puff-by-puff delivery of the gas-phase species is more remarkable because the lighting puff produces a disproportionate amount of the total analyte on a per cigarette basis for certain species. This trend has been well documented for formaldehyde $(6,8)$, but is also evident in this work for 1,3-butadiene, isoprene, acrylonitrile and to a lesser extent, 
Table 1. Kentucky reference $2 R 4 F$ puff-by-puff data

\begin{tabular}{|c|c|c|c|c|c|c|c|c|c|c|c|c|}
\hline \multirow[b]{2}{*}{ Compounds measured in MSS } & \multirow{2}{*}{$\begin{array}{c}\text { Puff } \\
1 \\
\end{array}$} & \multirow{2}{*}{$\begin{array}{c}\text { Puff } \\
2 \\
\end{array}$} & \multirow{2}{*}{$\begin{array}{c}\text { Puff } \\
3\end{array}$} & \multirow{2}{*}{$\begin{array}{c}\text { Puff } \\
4\end{array}$} & \multirow{2}{*}{$\begin{array}{c}\text { Puff } \\
5 \\
\end{array}$} & \multirow{2}{*}{$\begin{array}{c}\text { Puff } \\
6 \\
\end{array}$} & \multirow{2}{*}{$\begin{array}{c}\text { Puff } \\
7\end{array}$} & \multirow{2}{*}{$\begin{array}{c}\text { Puff } \\
8\end{array}$} & \multirow{2}{*}{$\begin{array}{c}\text { Puff } \\
9\end{array}$} & \multirow{2}{*}{$\begin{array}{c}\text { Sum } \\
\text { (per cig) }\end{array}$} & \multicolumn{2}{|c|}{ Historical data (per cig) ${ }^{2}$} \\
\hline & & & & & & & & & & & average & std. dev. \\
\hline \multicolumn{13}{|l|}{ NFDPM (mg/puff) } \\
\hline TPM & 0.72 & 0.94 & 1.15 & 1.27 & 1.37 & 1.50 & 1.62 & 1.71 & 1.73 & 12.0 & 11.5 & 0.5 \\
\hline Water & 0.06 & 0.06 & 0.08 & 0.10 & 0.09 & 0.10 & 0.12 & 0.15 & 0.23 & 0.98 & 0.94 & 0.15 \\
\hline Nicotine & 0.04 & 0.07 & 0.09 & 0.10 & 0.11 & 0.11 & 0.12 & 0.12 & 0.11 & 0.87 & 0.83 & 0.04 \\
\hline NFDPM & 0.62 & 0.81 & 0.98 & 1.07 & 1.17 & 1.30 & 1.38 & 1.43 & 1.39 & 10.2 & 9.72 & 0.43 \\
\hline \multicolumn{13}{|c|}{ Tobacco-specific nitrosamines (ng/puff) } \\
\hline NAB & 0.98 & 1.47 & 1.74 & 1.76 & 1.85 & 2.00 & 2.06 & 2.14 & 1.59 & 15.6 & 15.2 & 1.8 \\
\hline NAT & 9.02 & 11.3 & 13.5 & 14.3 & 14.7 & 15.1 & 16.6 & 16.8 & 12.0 & 123 & 121 & 17 \\
\hline NNK & 7.50 & 11.3 & 13.5 & 14.1 & 15.3 & 15.7 & 16.8 & 17.8 & 13.8 & 126 & 132 & 10 \\
\hline NNN & 8.72 & 13.3 & 15.7 & 16.7 & 18.0 & 18.4 & 19.9 & 21.2 & 15.2 & 147 & 145 & 11 \\
\hline \multicolumn{13}{|c|}{ Volatile organic compounds ( $\mu g /$ puff) } \\
\hline 1,3-Butadiene & 9.36 & 3.06 & 2.94 & 3.35 & 3.51 & 3.63 & 3.34 & 4.08 & 3.85 & 37.1 & 33.8 & 3.0 \\
\hline Isoprene & 81.9 & 34.0 & 32.9 & 36.4 & 38.5 & 40.0 & 37.9 & 47.6 & 42.0 & 391 & 385 & 26 \\
\hline Acrylonitrile & 1.55 & 0.75 & 0.76 & 0.88 & 0.92 & 0.95 & 0.92 & 1.26 & 1.32 & 9.30 & 9.00 & 0.90 \\
\hline Benzene & 7.29 & 4.80 & 4.80 & 5.34 & 5.57 & 5.75 & 5.40 & 6.75 & 6.11 & 51.8 & 48.2 & 3.1 \\
\hline Toluene & 7.39 & 8.24 & 8.43 & 9.16 & 9.47 & 9.85 & 9.64 & 12.8 & 13.0 & 88.0 & 82.8 & 6.0 \\
\hline Styrene & 0.60 & 0.50 & 0.45 & 0.50 & 0.56 & 0.62 & 0.68 & 1.02 & 1.30 & 6.23 & 6.00 & 0.80 \\
\hline \multicolumn{13}{|l|}{ Carbonyls ( $\mu g / p u f f)$} \\
\hline Formaldehyde & 6.60 & 1.43 & 1.29 & 1.45 & 1.37 & 1.50 & 1.47 & 1.60 & 1.49 & 18.2 & 21.7 & 4.0 \\
\hline Acetaldehyde & 68.2 & 42.5 & 45.4 & 56.3 & 57.0 & 65.4 & 71.0 & 81.1 & 75.4 & 562 & 635 & 65 \\
\hline Acetone & 20.9 & 19.5 & 21.2 & 25.9 & 26.0 & 29.5 & 31.7 & 37.2 & 35.7 & 248 & 282 & 29 \\
\hline Acrolein & 10.9 & 5.30 & 5.58 & 6.82 & 6.62 & 7.45 & 7.71 & 8.80 & 8.15 & 67.3 & 59.8 & 7.5 \\
\hline Propionaldehyde & 5.68 & 3.77 & 4.00 & 4.81 & 4.76 & 5.38 & 5.75 & 6.60 & 6.19 & 46.9 & 53.7 & 5.7 \\
\hline Crotonaldehyde & 1.16 & 0.99 & 1.08 & 1.39 & 1.40 & 1.65 & 1.85 & 2.39 & 2.54 & 14.5 & 19.7 & 3.4 \\
\hline Methyl ethyl ketone & 5.64 & 6.53 & 7.04 & 8.53 & 8.41 & 9.46 & 10.2 & 12.2 & 11.9 & 80.0 & 90.4 & 10.2 \\
\hline Butyraldehyde & 2.88 & 2.35 & 2.47 & 2.96 & 3.02 & 3.38 & 3.62 & 4.27 & 4.08 & 29.0 & 33.5 & 4.7 \\
\hline
\end{tabular}

${ }^{a}$ Internal laboratory method control data produced at Arista Laboratories.

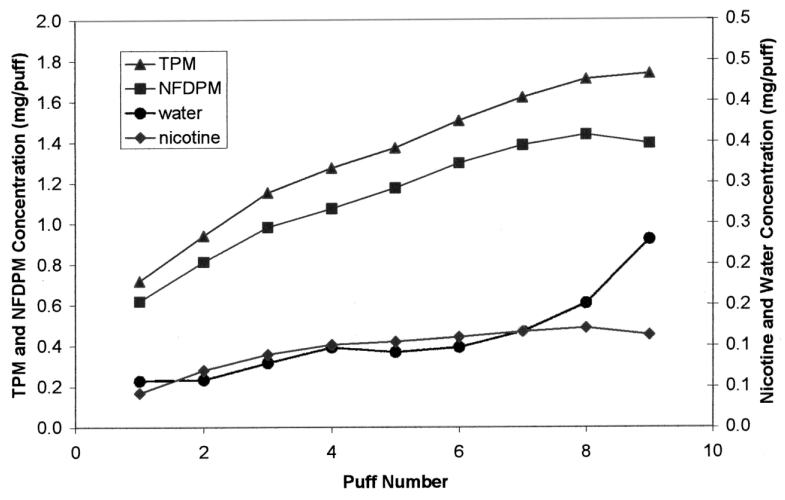

Figure 2. FTC 2R4F puff-by-puff delivery for NFDPM

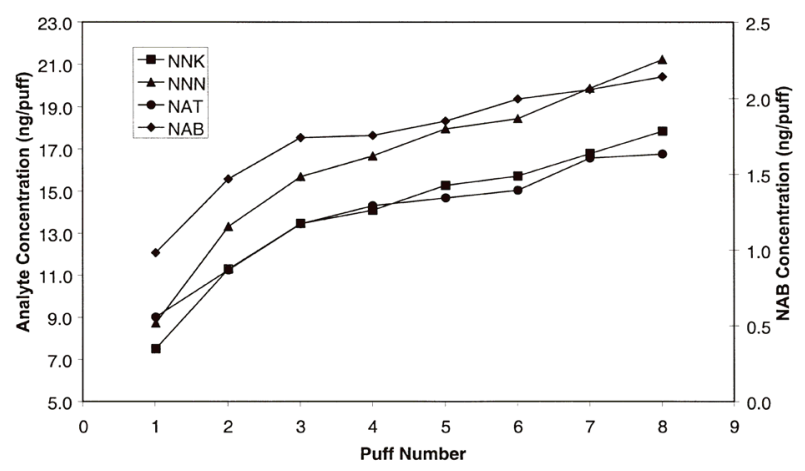

Figure 3. FTC 2R4F puff-by-puff delivery for TSNA

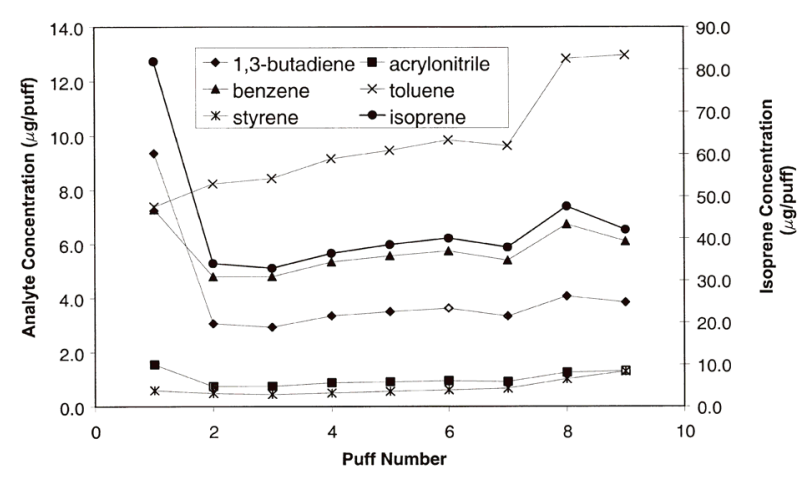

Figure 4. FTC 2R4F puff-by-puff delivery for VOCs

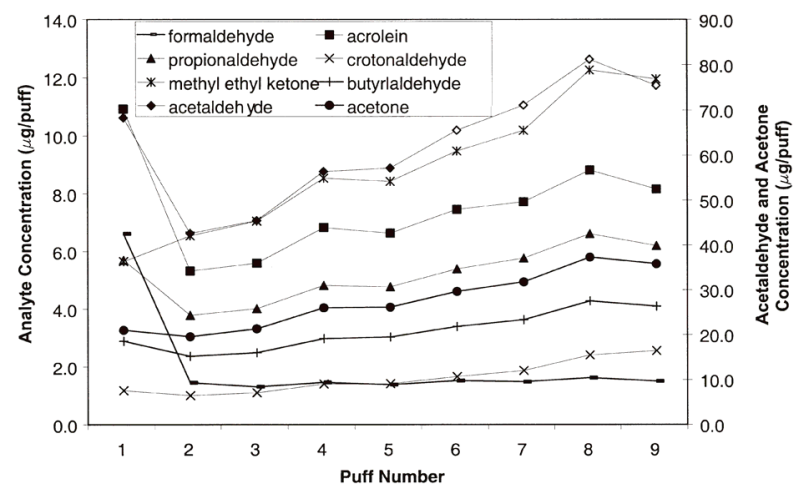

Figure 5. FTC 2R4F puff-by-puff delivery for carbonyls 


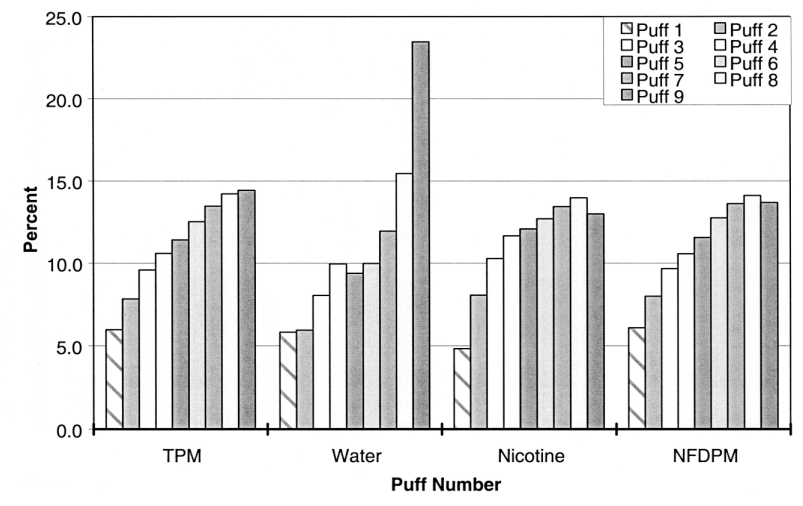

Figure 6. Percent NFDPM delivery per puff

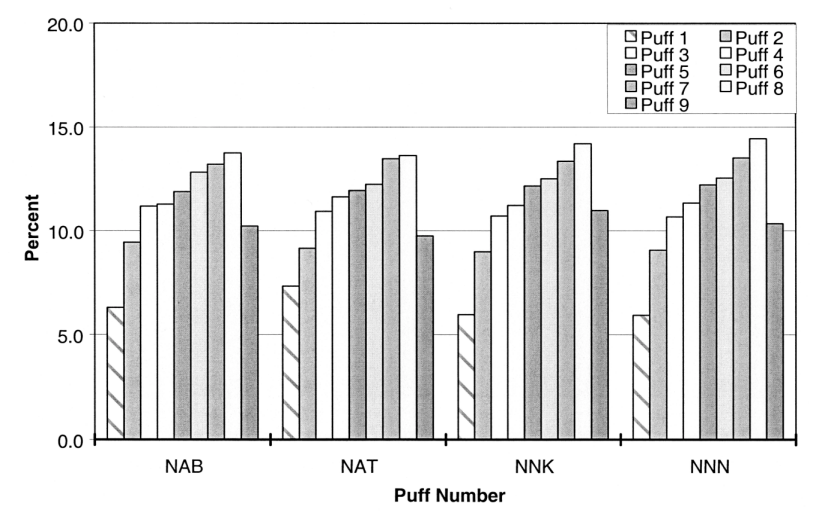

Figure 7. Percent TSNA delivery per puff

benzene, acetaldehyde, acrolein, and propionaldehyde. The percent analyte delivery, on a per puff basis is presented in Figures 6 to 9 for NFDPM, TSNA, VOCs, and carbonyls, respectively. These graphs clearly highlight the cigarette delivery profile. This type of information could be very useful when developing potential reduced exposure products. For instance, it might be possible to develop a novel cigarette that could selectively remove a constituent during the puff in which a large percentage of the constituent was generated, i.e. first puff, without drastically altering the overall smoking characteristics of the cigarette (8).

It should be noted that Borgwaldt Technik offers an accessory for the RM 20/CS smoker that has puff-by-puff analysis among its listed uses. The literature refers to the accessory as a "Twin Filter Smoke Trap" (part number R 25.00) (13). The description in the company's literature states that the accessory consists of a motor driven carousel that holds two Cambridge filter pad holders. When conducting puff-by-puff analysis, the carousel rotates to the second Cambridge filter after all 20 cigarettes have been puffed for a given puff number. Presumably, at that time, the operator would exchange the used Cambridge pad holder for a different holder containing an unused pad before the completion of the current puff cycle. The puff-by-puff apparatus presented in this work offers significant advantages compared to the Borgwaldt accessory for puff-by-puff analysis. Namely, the Borgwaldt accessory is not applicable for gas-phase analyses in which a liquid trap must be used. This is due to the fact that the trap must rotate. Other advantages are that the

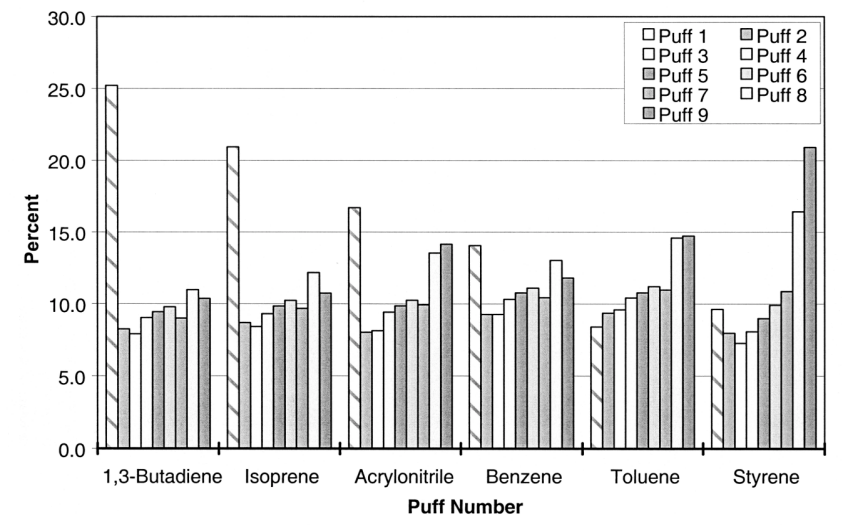

Figure 8. Percent VOC delivery per puff

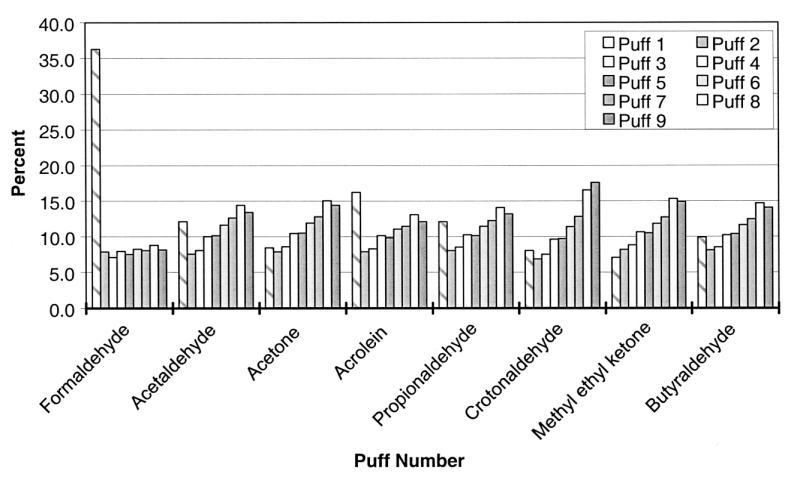

Figure 9. Percent carbonyl delivery per puff

proposed method has a very short, straight smoke path, which limits the amount of smoke condensate lost in transfer to the analytical trap and lastly, the airflow around the cigarettes does not need to be disturbed as would be the case with the Borgwaldt adapter when the Cambridge pad holder needs to be exchanged after every puff.

\section{CONCLUSION}

The puff-by-puff mainstream smoke collection method described provides the means to effectively collect the mainstream smoke from individual cigarette puffs for chemical analysis using the existing equipment and analytical methods found in many smoke chemistry laboratories. This method solves many of the major limitations of other puffby-puff methods presented in the literature, such as limited sensitivity, and limited applicability to a wide range of particulate- and gas-phase compounds. Puff-by-puff data are presented for the Kentucky reference $2 \mathrm{R} 4 \mathrm{~F}$ cigarette and the method is shown to produce results for NFDPM, TSNA, VOCs, and carbonyls that are in excellent agreement with traditional whole cigarette smoke analysis methods in which a few cigarettes are collected for each sample. Puff-by-puff data should prove useful in determining when smoke constituents are produced along the tobacco column. If a smoke constituent is produced in a disproportionately large amount in only one or two puffs, it can be targeted for selective removal without drastically altering the overall smoking characteristics of the cigarette. 


\section{ACKNOWLEDGEMENTS}

The assistance of the laboratory personnel who performed the analyses is gratefully acknowledged: Regina Ballentine, Randy Courington, Jiusheng Ye, Carolyn Silver, and Christy Coleman. I would also like to thank Sabine Back who performed the translation of the Summary section.

\section{REFERENCES}

1. Bondurant, S., P. Shetty, R. Wallace, and K. Stratton (Eds.): Clearing the Smoke, Chapter 4, Products for tobacco exposure reduction; National Academy Press, Washington D.C., 2001, pp. 82-139.

2. Bondurant, S., P. Shetty, R. Wallace, and K. Stratton (Eds.): Clearing the Smoke, Chapter 10, Tobacco smoke and toxicology; National Academy Press, Washington D.C., 2001, pp. 283-308.

3. Green, C. and M. Dube: Methods of collection of smoke for analytical purposes; Rec. Adv. Tob. Sci. 8 (1982) 42-102.

4. Lyons-Hart, J., K. Shafer, and M. Parrish: Puff-bypuff and intrapuff analysis of cigarette smoke using infrared spectroscopy; Vib. Spec. 27 (2001) 29-42.

5. Harward, C. and M. Parrish: Measurement of formaldehyde in a single puff of cigarette smoke using tunable diode laser infrared spectroscopy; Appl. Spec. 54 (2000) 1665-1677.

6. Koller, K. and C. Thomas; Puff-by-puff mainstream analysis by multiplex gas chromatography spectrometry; Beitr. Tabakforsch. Int. 19 (2001) 345-351.
7. Lafaye, A. and P. Ceschini; Evolution of the gas-vapor phase and the total particulate matter of cigarette smoke in a single puff; Beitr. Tabakforsch. Int. 8 (1976) 378-381.

8. Li, S., M. Parish, S. Plunkett, and K. Shafer: Cigarette with smoke constituent attenuator, US Patent Number 6,701,936 (2004, March 9).

9. Dwyer, R.W. and P. Chen; A puff-by-puff delivery model for cigarettes; Beitr. Tabakforsch. Int. 20 (2002) 273-277.

10. Lymn, D. and E.L. Crooks; The measurement of intrapuff nicotine; Beitr. Tabakforsch. Int. 15 (1992) 75-86.

11. Federal Trade Commission: Cigarettes. Testing for "tar" and nicotine content - statements of consideration; Federal Register 32, 11178, 1967.

12. ISO 4387: Cigarettes. Determination of total and nicotine-free dry particulate matter using routine analytical smoking machine; International Organization for Standardization, Geneva, 2000.

13. Borgwaldt Technik RM 20/CS smoking machine manual, R20.0823.00 E, Heinr. Borgwaldt, Hamburg, Germany.

\section{Corresponding author}

K.A. Wagner

Philip Morris USA

615 Maury Street, $R D \& E$

Richmond, VA 23224

USA

Email:karl.a.wagner@pmusa.com 